\title{
PENYEMPROTAN DESINFEKTAN
}

(KELURAHAN BONTOTANGNGA KEC.TAMALATEA)

NAMA : TITIK KAMAL

NIM : 9173770410181

EMAIL : ktiti0573@gmail.com

1. Bentuk Kegiatan

- Penyemprotan Masjid, Kantor Camat dan Kantor Lurah

2. Lokasi

- Kelurahan Bontongnga

3. Hari Tanggal Dan Waktu

- Setiap Hari Jumat, Tanggal 02-Oktober-2020/ Pukul 08.00-11.00 Wita sampai Tanggal 23Oktober-2020

4. Peserta Yang Dilibatkan

- Mahasiswa KKLP YAPTI JENEPONTO

5. Alasan yang Diadakannya

- $\quad$ Untuk mengurangi penyebaran terjangkitnya Covid-19

6. Tujuan dan Manfaat

- $\quad$ Untuk Memutus rantai Penyebaran Covid-19.

7. Deskripsi Kegiatan

- Kegiatan ini dilakukan dimulai dari penyemprotan Masjid, Kantor Lurah, dan Kantor Camat di pagi hari, 